\title{
Targeting Protease-Activated Receptor- 1 with Cell-Penetrating Pepducins in Lung Cancer
}

\author{
Jaroslaw Cisowski, ${ }^{*}$ Katie O'Callaghan, * \\ Athan Kuliopulos, ${ }^{\star \dagger}$ John Yang, ${ }^{\ddagger}$ Nga Nguyen, ${ }^{*}$ \\ Qing Deng, ${ }^{\S}$ Eric Yang, ${ }^{+\uparrow \uparrow}$ Michael Fogel, ${ }^{\ddagger}$ \\ Sarah Tressel, ${ }^{*}$ Caitlin Foley, ${ }^{\|}$Anika Agarwal, ${ }^{*}$ \\ Stephen W. Hunt III, ${ }^{\S}$ Tom McMurry, $§$ \\ Larry Brinckerhoff, ${ }^{* *}$ and Lidija Covic ${ }^{* \dagger}$ \\ From the Molecular Oncology Research Institute, the Division of \\ Hematology/Oncology, ${ }^{\ddagger}$ and the Department of Cardiotboracic \\ Surgery and General Surgery and Thoracic Surgery,** Tufts \\ Medical Center, Boston; the Departments of Biochemistry, ${ }^{\dagger}$ \\ Medicine," and Genetics," Tufts University School of Medicine, \\ Boston; and Anchor Therapeutics, ${ }^{\S}$ Cambridge, Massachusetts
}

Protease-activated receptors (PARs) are G-proteincoupled receptors that are activated by proteolytic cleavage and generation of a tethered ligand. High PAR1 expression has been documented in a variety of invasive cancers of epithelial origin. In the present study, we investigated the contribution of the four PAR family members to motility of lung carcinomas and primary tumor samples from patients. We found that of the four PARs, only PAR1 expression was highly increased in the lung cancer cell lines. Primary lung cancer cells isolated from patient lung tumors migrated at a 10 - to 40 -fold higher rate than epithelial cells isolated from nonmalignant lung tissue. Cellpenetrating pepducin inhibitors were generated against the first (i1) and third (i3) intracellular loops of PAR1 and tested for their ability to inhibit PAR1driven migration and extracellular regulated kinase (ERK)1/2 activity. The PAR1 pepducins showed significant inhibition of cell migration in both primary and established cell lines similar to silencing of PAR1 expression with short hairpin RNA (shRNA). Unlike i1 pepducins, the $i 3$ loop pepducins were effective inhibitors of PAR1-mediated ERK activation and tumor growth. Comparable in efficacy with Bevacizumab, monotherapy with the PAR1 i3 loop pepducin P1pal-7 provided significant $75 \%$ inhibition of lung tumor growth in nude mice. We identify the PAR1-ERK1/2 pathway as a feasible target for therapy in lung cancer. (Am J Pathol 2011, 179:513-523; DOI: 10.1016/j.ajpath.2011.03.025)
Lung cancer is the leading cause of cancer deaths in the United States and worldwide, and is the second most common cancer overall. ${ }^{1}$ The majority of patients eventually develop distant metastases, which leads to substantial morbidity and mortality. Currently available chemotherapeutic regimens for the treatment of non-small-cell lung cancer (NSCLC) include combinations of cisplatin or carboplatin, and etoposide, paclitaxel, docetaxel, gemcitabine, vinorelbin, and irinotecan. These regimens are generally not curative and may confer modest prolongation of life and symptomatic relief. 2,3 More recently, targeted therapies have become available for the treatment of lung cancer. These include small molecules and antibodies that target epidermal growth factor receptor and vascular endothelial growth factor receptor. However, the currently available molecular therapies still result in relatively modest prolongation of median and overall survival, pointing to the necessity for developing more effective treatment modalities for patients with advanced NSCLC.

Emerging evidence has identified protease activated receptor-1 (PAR1) as a promising target to impact tumor progression, metastasis, and angiogenesis in a variety of cancers including breast, ovarian, melanoma, prostate, and colon cancer. ${ }^{4-7}$ However, the role of PAR1 and the other PAR family members in lung cancer is largely unexplored. To date, four different PARs have been identified: PAR1, PAR2, PAR3, and PAR4. 8,9-13 PAR1 originally was discovered on platelets and serves as the prototype for this specialized class of proteolytically activated G-protein-coupled receptors (GPCRs). ${ }^{8}$ PAR 1 is activated when it is cleaved by thrombin between residues $R_{41}$ and $S_{42}$, located within the $\mathrm{N}$-terminal extracellular domain of the receptor. PAR3 and PAR4 also are activated by thrombin, whereas PAR2 is a trypsin/tryptase receptor. ${ }^{14}$ Proteolytic cleavage exposes a new $\mathrm{N}$-terminus that binds to the body

Supported by NIH grants CA104406 (L.C.) and a fellowship from Aid for Cancer Research, Boston, MA (E.Y.), and CA122992 (A.K.).

Accepted for publication March 21, 2011.

Supplemental material for this article can be found at http://ajp. amjpathol.org or at doi:10.1016/j.ajpath.2011.03.025.

Address reprint requests to Lidija Covic, Ph.D., Division of Hematology/ Oncology, Molecular Oncology Research Institute, Tufts Medical Center, Box 7510, 750 Washington St., Boston, MA 02111. E-mail: Icovic@ tuftsmedicalcenter.org. 
of the receptor in an unusual intramolecular mode. It recently was shown that matrix metalloprotease- 1 also can cleave and activate PAR1 at a distinct site: $\mathrm{D}_{39}-\mathrm{P}_{40} \cdot{ }^{4,15}$ Synthetic peptides that correspond to the first few amino acids of the freshly cleaved N-terminus of the PARs (eg, SFLLRN PAR1, TFLLRN ${ }^{\text {PAR1 }}$, PRSFLLRNPAR1, SLIGRL PAR2, and AYPGKF ${ }^{\text {PAR4 }}$ ), also can function as selective intermolecular agonists to PARs. $8,16,17$

PAR1, the major thrombin receptor, is a GPCR shown to influence a wide range of physiological and pathologic processes of the cardiovascular system, including endothelial barrier function, vasoreactivity, intimal hyperplasia, inflammation, and hemostasis. ${ }^{18}$ PAR1 is a mediator of proliferation and migration of endothelial cells in vitro and is essential for angiogenesis in the developing mouse. ${ }^{19}$ PAR1-deficiency in mice results in lethality of half the embryos at midgestation (E9.5) owing to defective blood vessel formation. ${ }^{19}$ Surprisingly, PAR1-deficient mice had no altered platelet function phenotypes, leading to the discovery of PAR4. ${ }^{13}$ Unlike in humans, PAR4 is the major thrombin receptor on mouse platelets from PAR4-deficient mice do not signal to thrombin. PAR2 is widely expressed in inflammatory cells, stroma, endothelium, and intestinal epithelium. ${ }^{18}$ PAR2 has been implicated in the progression of liver fibrosis potentially via coagulation factor $\mathrm{Xa}$, which may trigger proinflammatory responses in inflammatory cells. ${ }^{20}$ The functional role of PAR3 is unclear and the synthetic PAR3 tethered ligand TFRGAP does not stimulate detectable downstream signaling. ${ }^{13}$ PARs also have been shown to form functional heterodimers. PAR1 and PAR3 can serve as co-factors for PAR4, ${ }^{13,21}$ and PAR1 can transactivate PAR2. ${ }^{22}$

Each PAR couples to a distinct subset of $G$ proteins. For instance, PAR 1 couples with $G \alpha$-subunits $G_{\mathrm{q}}$, $\mathrm{G}_{\mathrm{i}}$, and $\mathrm{G}_{12 /}$ 13 , which are activated differentially by different proteases. Thrombin can concomitantly activate all three heterotrimeric subunits whereas matrix metalloprotease- 1 more selectively activates $G_{12 / 13}$ signaling. ${ }^{15}$ PAR $1-G_{\mathrm{q}}$ stimulates phospholipase $\mathrm{C}-\beta$ generation of $\operatorname{InsP}_{3}$, which mobilizes $\mathrm{Ca}^{2+}$ and diacylglycerol, which activates protein kinase $\mathrm{C}-\alpha$. These in turn activate phospholipase $A_{2}$ and phospholipase $D$. $G_{12 / 13}$ plays a major role in cell shape change, migration, and rho-dependent oncogenesis. We previously have shown that a switch in $G$-protein signaling from $G_{12 / 13}$ to $G_{i}$ occurs in the context of PAR1-PAR2 heterodimers and is involved in the maintenance of endothelial barrier function. ${ }^{22} G_{i}$ is involved in activation of rac and inhibition of adenylate cyclase and suppression of cAMP. It is still not understood how PAR1 regulates the mitogen-activated protein kinase cascade members such as ERK $1 / 2$.

In addition to their well-recognized roles in vascular biology, PARs also have been proposed to be involved in the regulation of survival, apoptosis, and tumor growth. ${ }^{7}$ PAR1 and PAR2 are important in tumor cell motility in melanoma ${ }^{23,24}$ and PAR1 is involved in the invasive and metastatic processes of breast, ${ }^{25,26}$ ovarian, ${ }^{6}$ and pancreatic cancer. ${ }^{27}$ PAR1 also has been identified as an oncogene in the transformation of NIH3T3 mouse fibroblasts $^{28,29}$ and ectopic expression of PAR1 confers tumorigenicity in PAR1-null breast carcinoma cells. ${ }^{4}$ Recent work by Ghio et al ${ }^{30}$ measured PAR1, PAR4, and vascular endothelial growth factor (VEGF) expression in
60 NSCLCs that consisted of 30 adenocarcinomas and 30 squamous cell carcinomas. They found that the majority of lung tumors expressed VEGF and that there was a significant correlation between PAR1 and/or PAR4 expression with VEGF. Moreover, there was a trend toward shorter 3-year survival in PAR1-positive lung cancers. ${ }^{30}$

In the present study, we identified PAR1 as a potential therapeutic target in lung cancer by using cell-penetrating pepducins generated from the first (i1) intracellular and third (i3) intracellular loops of PAR1.

Pepducin technology was developed to target receptor G-protein interactions at the interface of the plasma membrane. Palmitoylation or use of other lipid moieties attached to the peptide partitions the lipopeptide across the plasma membrane and rapidly delivers pepducin to the intracellular surface by flipping across the bilayer. Multiple studies have been performed to determine the specificity of pepducins to their cognate receptors. ${ }^{22,31-34}$ We found that PAR1 pepducins based on the $\mathrm{i} 1$ and i3 loops had comparable efficacy in inhibiting migration and $\mathrm{Ca}^{2+}$ signaling. In contrast, i3-targeted pepducins also could block PAR1-dependent ERK $1 / 2$ activity and VEGF secretion. Monotherapy with i3based pepducins was more efficacious than with i1-based pepducins, and PAR1 inhibited with i3 pepducins significantly inhibited lung tumor growth by up to $75 \%$ in xenograft models, and was similar in efficacy to Avastin (Genentech, San Francisco, CA). These studies identify PAR1 as a promising new therapeutic target in lung cancer and show that pepducins based on 11 and i3 loops of PAR1 can block different signaling pathways.

\section{Materials and Methods}

\section{Cells and Reagents}

A549, HOP62, H1299, HOP92, H226, H522, H23, and EKVX lung carcinoma cell lines were obtained from Developmental Therapeutics at the National Cancer Institute/NIH. Cells were cultured in RPMI 1640 containing 10\% fetal bovine serum, $0.15 \%$ sodium bicarbonate, $10 \mathrm{U} / \mathrm{mL}$ penicillin and $10 \mathrm{mg} / \mathrm{mL}$ streptomycin. All cells were grown at $37^{\circ} \mathrm{C}$ in an atmosphere of $5 \% \mathrm{CO}_{2}$. Fibroblast conditioned media was derived from NIH3T3 or CRL-2076 obtained from American Type Culture Collection. VEGF was measured using an enzyme-linked immunosorbent assay (R\&D Systems, Minneapolis, MN) following the manufacturer's protocols. Small interfering RNA against PAR1 was synthesized by Dharmacon (Chicago, IL) and was transfected into cancer cells as previously described. ${ }^{7}$ Pepducins P1pal-7 (palmitateKKSRALF), P1pal-10S (palmitate-NRSKKSSALF), P1pal11-11 (palmitate-ILKMKVKKPAV), P1pal-19EE (palmitateRCESSSAEANRSKKERELF), X1/2pal-i1, ${ }^{33}$ and $\mathrm{X} 1 / 2$ pal-i $3^{33}$ were synthesized with $\mathrm{C}$-terminal amides by standard 9-fluorenylmethyloxycarbonyl solid-phase methods. ${ }^{31,35}$ Polyclonal antibodies against PAR1, PAR3, and PAR4 were generated in our laboratory and purified by peptide affinity chromatography as described previously. ${ }^{36}$ In addition, polyclonal antibodies against PAR1, PAR2, PAR3, and PAR4 were purchased from Santa Cruz (Santa Cruz, CA). 
PAR surface expression was quantified by flow cytometry on lung carcinoma cells as described previously. ${ }^{5}$

\section{Isolation and Culture of Primary Lung Cancer Cells from Patients}

After approval by the Tufts Medical Center Institutional Review Board, human lung tissues were obtained from de-identified patients who underwent surgery at Tufts Medical Center for removal of invasive lung tumors. Samples were immediately frozen in liquid nitrogen and later used for RNA analysis. Additional tissue samples were finely minced with a razor blade ${ }^{5}$ and digested with 10 $\mathrm{U} / \mathrm{mL}$ collagenase type 1 in RPMI 1640 for 20 minutes at $37^{\circ} \mathrm{C}$

\section{Cell Migration}

To assess cell migration, Transwell plates (24-well) with cell culture inserts $6.5 \mathrm{~mm}$ in diameter with $8-\mu \mathrm{m}$ pore size were used (BD Biosciences, Woburn, MA). Cells were seeded into the upper chamber at a density of $4 \times 10^{4}$ per $\mathrm{mL}$ in medium containing $0.1 \%$ bovine serum albumin, and $\mathrm{NIH} 3 \mathrm{~T} 3$ conditioned medium was added into the lower chamber as previously described. ${ }^{4}$ The number of cells was determined by microscope using $\times 160$ magnification. Results were presented as the total number of cells that migrated in nine fields.

\section{Cell Viability Assay}

Cells were seeded into 96-well plates at a density of $3 \times 10^{3}$ in $10 \%$ fetal bovine serum. The next day media was changed to $0.5 \%$ fetal bovine serum, $0.1 \%$ bovine serum albumin in RPMl, and cells were stimulated with $0.3 \mathrm{nmol} / \mathrm{L}$ thrombin in the presence of various concentrations of pepducin ( 1 to $30 \mu \mathrm{mol} / \mathrm{L}$ ) or vehicle. After 5 hours or 72 hours, media was removed and MTT solution $(0.5 \mathrm{mg} / \mathrm{mL})$ was added into each well for 5 hours. MTT crystals were solubilized in $100 \mu \mathrm{L}$ of dimethyl sulfoxide. Absorbance was measured at 570 and $670 \mathrm{~nm}$ using a microtiter plate reader. Results were calculated according to the equation $A_{570}-A_{670}$ and were presented relative to unstimulated cells.

\section{Stable Silencing of PAR1 using Lentiviral Delivery of Short Hairpin RNA}

Stable silencing of PAR1 was performed using a lentiviral vector approach. Lentivirus was produced in HEK293T cells transfected with the envelope plasmid, pMD.G, the packaging plasmid, pCMV-dR8.9, and either pLKO.1-puroshPAR1 (5'-CCTACTACTTCTCAGCCTTCT-3') or PLKO.1puro-short hairpin Luciferase (5'-CGCTGAGTACTTCGAAATGTC-3') using the calcium phosphate transfection method. Viral particles in the supernatant were harvested 24 hours after transfection and filtered to remove cellular debris. The lung cancer cell lines HOP62 and A549 were plated at $75 \%$ confluency in 6-well plates and infected overnight with viral supernatant diluted 1:100 in the presence of polybrene ( $8 \mathrm{mg} / \mathrm{mL})$. The next day, virus-containing media was removed and replaced with normal growth media supplemented with $1 \mathrm{mg} / \mathrm{mL}$ (HOP62) or $2 \mathrm{mg} / \mathrm{mL}$ (A549) puromycin. Cells were characterized for PAR1 expression by flow cytometry and a functional migration assay was conducted as previously described.

\section{Western Blotting}

Cells were lysed in NP-40 buffer $(150 \mathrm{mmol} / \mathrm{L} \mathrm{NaCl}, 1 \%$ $\mathrm{NP}-40,50 \mathrm{mmol} / \mathrm{L}$ Tris, $\mathrm{pH}$ 8.0) supplemented with pronase inhibitors, aprotinin, and leupeptin (Sigma-Aldrich, St. Louis, MO) and phosphatase inhibitor cocktail (Roche, Branchburg, NJ). The lysates were cleared by centrifugation and protein content in the resulting supernatants was determined by Bradford assay. Protein samples (30 to $50 \mu \mathrm{g}$ ) were resolved in 12\% Tris-SDS gel and transferred to nitrocellulose membranes. The membranes were blocked for 1 hour in 5\% non-fat milk and incubated with phospho-ERK $1 / 2$ and total ERK1/2 (Cell Signaling Technologies, Danvers, MA) antibodies overnight at $4^{\circ} \mathrm{C}$. Horseradish-peroxidase-conjugated secondary antibodies were used to detect the complexes of primary antibodies with target proteins.

\section{Tumor Growth in Nude Mice}

All animal experiments were conducted in full compliance with the Institutional Animal Care and Use Committee of Tufts Medical Center. A549 cells $\left(4 \times 10^{6}\right)$ were implanted bilaterally under the skin on the flanks of 6 - to 8-week-old female NCR nu/nu mice (Taconic Farms, Hudson, NY). Each group had 5 animals with 2 tumors per mouse $(n=10)$. Mice were injected with P1pal-7 (10 $\mathrm{mg} / \mathrm{kg}$ ), P1pal-10S (10 mg/kg), P1pal-i1-11 (10 mg/kg), X1/2pal-i3 (3 mg/kg), and X1/2pal-i1 (3 mg/kg) pepducins, or vehicle (20\% dimethyl sulfoxide) daily, 6 days per week. Avastin (5 mg/kg; Roche) was injected twice a week. All injections were performed subcutaneously into the flanks of mice. Tumor growth was monitored for up to 90 days using calipers, after which time the mice were euthanized. Tumor length and width were measured and volume was calculated by the equation: volume $=$ (length $\times$ width $\left.^{2}\right) / 2$. Tumors were formalin-fixed and paraffinembedded, sectioned, and stained with H\&E at the Department of Pathology of Tufts Medical Center.

\section{Cytosolic Calcium Measurements}

Blood samples were obtained from healthy adult volunteers who had not used aspirin within 7 days. Whole blood was drawn into a 30-mL syringe with $10 \% \mathrm{v} / \mathrm{v}$ sterile sodium citrate as anticoagulant using an 18-gauge needle. Informed consent and blood collection were approved by the Tufts Medical Center Institutional Review Board. Platelet-rich plasma was prepared by centrifuging whole blood for 25 minutes at room temperature at $250 \times$ $g$. The anticoagulants EDTA ( $1.0 \mathrm{mmol} / \mathrm{L}$ final) and apyrase $(0.1 \mathrm{U} / \mathrm{mL}$ final) (Sigma-Aldrich, St. Louis, MO) were added to the platelet-rich plasma. Platelets were isolated from platelet-rich plasma by Sepharose-2B gel filtration 
(GE Healthcare, Piscataway, NJ) in modified PiperazineN,N'-bis[2-ethanesulfonic acid (PIPES)]-buffered saline (25 mmol/L PIPES, $137 \mathrm{mmol} / \mathrm{L} \mathrm{NaCl}, 4 \mathrm{mmol} / \mathrm{L} \mathrm{KCl}, 0.1 \%$ glucose, pH 6.7) as previously described. Platelets were resuspended and washed in PIPES buffer and loaded with $2.5 \mu \mathrm{mol} / \mathrm{L}$ fura-2/AM (Molecular Probes, Eugene, OR) for 30 minutes at $37^{\circ} \mathrm{C}, 5 \% \mathrm{CO}_{2}$, with gentle shaking. Fluorescence was measured in a Perkin-Elmer (Waltham, MA) LS50B spectrofluorimeter as previously described. The fluorescence emission was recorded at $510 \mathrm{~nm}$ and dual excitation was recorded at 340 and $380 \mathrm{~nm}$. Platelet $\mathrm{Ca}^{2+}$ experiments were performed without stirring at $25^{\circ} \mathrm{C}$.

\section{Quantitative PCR}

Total RNA was extracted using the RNeasy kit (Qiagen, Valencia, CA). cDNA was amplified as previously described $^{37}$ and QPCR was conducted using iQ Syber Green Supermix (Bio-Rad, Hercules, CA) and specific primers for PAR1 to PAR4 and actin. PAR1 primers: 1.5', 5' -ATTGTGTCGCTTCGTCACTG-3', 1. 3' , 5' -GAGAGGGACTGCATGGGATA-3'; PAR2 primers: Par-2.5', 5'-ATCCCACGTCACTGGAAAAG-3', Par-2.3', 5'-ATCACAGCAGGGTGCTTCTT-3'; PAR 3 primers: Par3.5', 5'-GGTGTGGGCAACAGTTTTCT-3', Par-3.3', 5'GGACTCGCAAGTGTTGTGAA-3'; PAR4 primers: Par4.5', 5'-CCAGCGTCTACGACGAGAG-3'; Par-4.3', 5'ACCAGGACCAGCCCATAGAG-3'; $\beta$-actin: sense, $5^{\prime}$ GGCTCTTCCAGCCTTCCTTCCT-3', antisense, 5'-CACAGAGTACTTGCGCTCAGGAGG-3'.

\section{Pharmacokinetics of Subcutaneously Injected Pepducins in Mouse Plasma}

CF-1 mice were injected subcutaneously with 3 or 10 $\mathrm{mg} / \mathrm{kg}$ of P1pal-7, P1pal-10S, or P1pal-i1-11 in 20\% dimethyl sulfoxide and blood was collected at various time points from the vena cava into $5 \mu \mathrm{L} 1000 \mathrm{U}$ heparin. Pepducins were extracted from $100 \mu \mathrm{L}$ plasma plus $600 \mu \mathrm{L} 2 \%$ formic acid in acetonitrile and then vortexed and centrifuged. The supernatant was removed and $500 \mu \mathrm{L} 2 \%$ formic acid in water was added and $100 \mu \mathrm{L}$ was injected onto an liquid chromatography-mass spectrometry (LC/MS/MS) ABI 4000 Qtrap in ESI+MRM (Charles River, Wilmington, MA) mode.

\section{Statistical Analysis}

Unless otherwise indicated, all results are presented as mean \pm SE. Comparisons were made with the Student's $t$-test. Statistical significance was defined as $P<0.05$ and $P<0.01$ (Figures 3-5).

\section{Results}

\section{Targeting PAR1 G-Protein Signaling Using Pepducin Technology}

We previously developed cell-penetrating peptides, termed pepducins, based on the intracellular domains of
PAR $1^{4,31}$ and other GPCRs. ${ }^{21,22,38}$ Pepducins based on the $i 1$ and i3 loops have proven to be potent inhibitors of chemokine receptors ${ }^{32}$ and PAR4. ${ }^{21,35}$ To guide in the design of 11 and i3 pepducins, a model of PAR1 based on the X-ray structure of rhodopsin ${ }^{39}$ was generated ${ }^{40}$ as shown in Figure 1A. Because different PAR1 intracellular loops are predicted to interact with distinct regions of the heterotrimeric $G_{q}, G_{i}$, and $G_{12 / 13}$ proteins it was of interest to test whether intracellular blockade of i1 versus i3 loops would preferentially affect different signaling pathways. Therefore, we tested the efficacy of the i3-loop P1pal-7, the i3-loop P1pal-10S, and the i1-loop P1pali1-11 for their ability to block PAR1-mediated $\mathrm{Ca}^{2+}$ signaling, cell migration, and mitogen-activated protein kinase signaling because these are regulated by different signaling pathways. It previously was shown ${ }^{41,42}$ that PAR1 strongly couples to $G_{\mathrm{a}}$ in human platelets as assessed by $\mathrm{Ca}^{2+}$ signaling. To determine the effect of i1 and i3 pepducins on PAR1-mediated $\mathrm{G}_{\mathrm{q}}$-phospholipase C beta-inositol 1,4,5-triphosphate signaling we pretreated human platelets with PAR1 pepducins stimulated with SFLLRN and measured $\mathrm{Ca}^{2+}$ flux. As shown in Figure 1B, P1pal-7, P1pal-10S, and P1pal-i1-11 effectively inhibited PAR1-dependent $\mathrm{Ca}^{2+}$ mobilization by SFLLRN with $\mathrm{IC}_{50}$ values of $0.55 \pm 0.04,0.70 \pm 0.17$, and $1.3 \pm$ $0.1 \mu \mathrm{mol} / \mathrm{L}$, respectively. However, unlike the i3-derived pepducin, which could completely inhibit calcium mobilization, the i1-derived P1pal-i1-11 was less effective in inhibiting the $\mathrm{G}_{\mathrm{q}}$-mediated calcium signal.

Using Boyden chamber (Cell Biolabs, Inc., San Diego, CA) migration assay, we showed that both thrombin and the matrix metalloprotease-1 tethered PAR1-ligand peptide, PRSFLLRN, and induced migration of A549 cells with a similar magnitude (Figure $1 C$ ). Next, we examined whether the PAR1 antagonist pepducins could block migration of the A549 lung adenocarcinoma. As shown in Figure $1 \mathrm{C}$, there was a complete blockade of migration of A549 cells to both thrombin and PRSFLLRN by either i1or i3-derived pepducins.

There has been great interest in understanding the mechanism of PAR1-mediated activation of mitogen-activated protein kinase cascade and PAR1-dependent celIular growth and differentiation, proliferation, and gene transcription. ${ }^{43-46}$ ERK $1 / 2$ activation has been shown to be activated through both $G_{i}(\beta \gamma)$-phosphatidylinositol 3-kinase and $G_{a}$ pathways. ${ }^{47}$ We examined the effects of 11 versus i3 PAR1 pepducins on ERK $1 / 2$ activation in the A549 lung adenocarcinoma cell line. Treatment of A549 cells with thrombin resulted in a rapid and robust ERK $1 / 2$ phosphorylation that peaked 15 to 30 minutes after stimulation (see Supplemental Figure S1A at http:// ajp.amjpathol.org). We conducted inhibition experiments with a range of pepducin concentrations ( 0.1 to $3 \mu \mathrm{mol} /$ L). There was complete inhibition of thrombin-induced ERK 1/2 phosphorylation with the i3-derived pepducins, P1pal-7 and P1pal-10S, with $I C_{50}$ values of $0.2 \pm 0.1$ and $0.8 \pm 0.2 \mu \mathrm{mol} / \mathrm{L}$, whereas the i1-derived P1pal-i1-11 had no effect on the thrombin-mediated phosphorylation of ERK1/2 (Figure 2, A and D). The PRSFLLRN peptide gave 

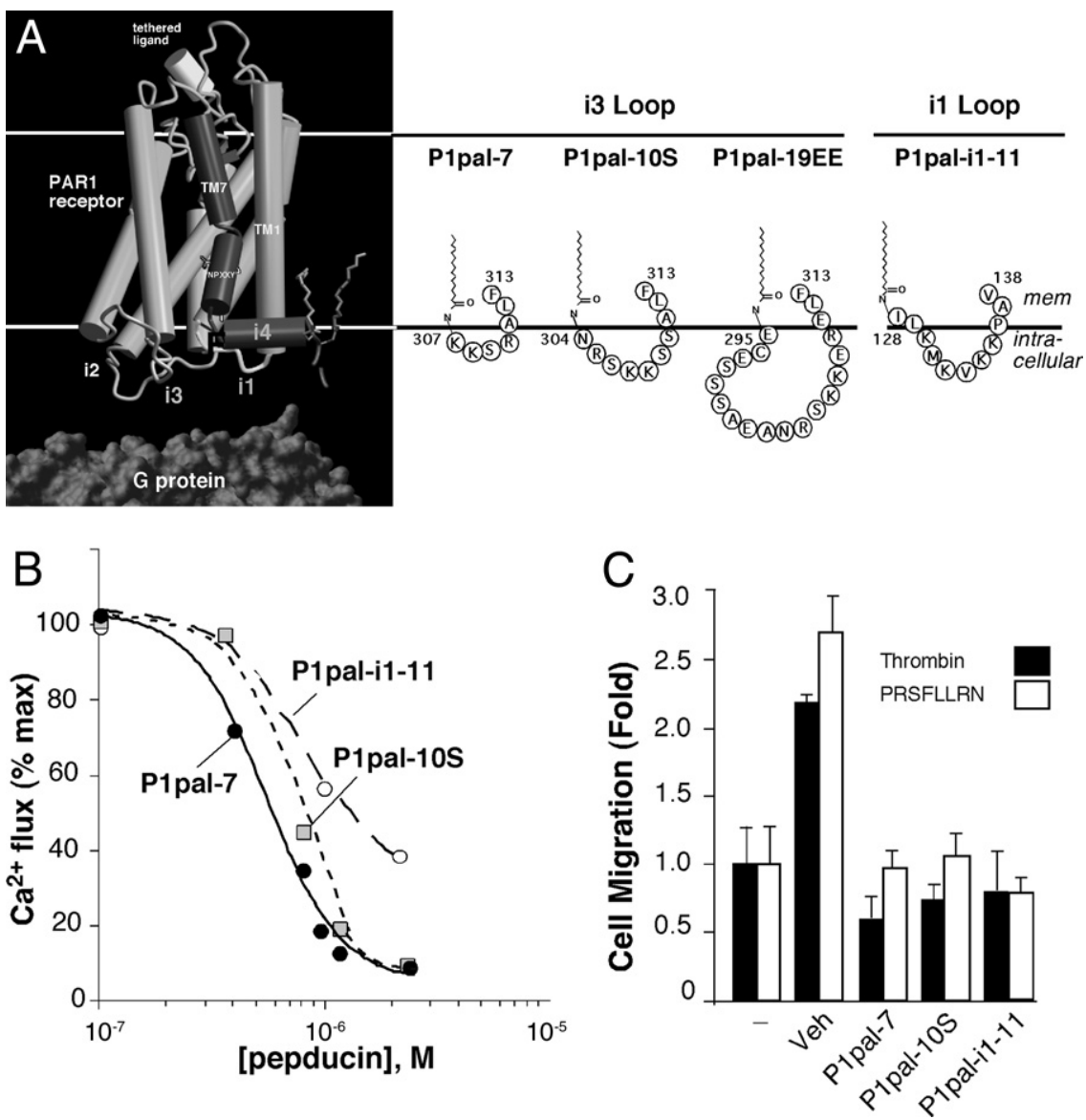

Figure 1. Membrane-tethered PAR1-i3 and i1 pepducins block $\mathrm{Ca}^{2+}$ flux and migration. A Model of PAR1 based on the X-ray structure of rhodopsin from Swift et al. ${ }^{40}$ Protease cleaved receptor results in generation of a new tethered ligand. The topologic arrangement of the i1 to i4 loops and $\mathrm{G}$ proteins are illustrated. Schematic diagram of palmitoylated PAR1 i3 and i1 pepducins and their amino acid sequence composition are shown. B: Effect of PAR1 pepducins on human platelets $\mathrm{Ca}^{2+}$ flux. ${ }^{35}$ Platelets were preincubated with indicated concentrations of pepducins and stimulated with SFLLRN. Effect of blockade is expressed as the percentage of full $\mathrm{Ca}^{2+}$ signal generated with SFLLRN in the absence of inhibitors. C: Migration of A549 cells toward $0.3 \mathrm{nmol} / \mathrm{L}$ thrombin or $10 \mu \mathrm{mol} / \mathrm{L}$ PRSFLLRN in the presence or absence of $3 \mu \mathrm{mol} / \mathrm{L}$ P1pal-7, P1pal-10S, or P1pal-i1-11 after 18 hours. Basal migration (-), migration of A549 cells toward PAR1 ligand (Veh). Cell migration is expressed as fold migration of ligand-mediated migration divided by basal migration. a rapid and transient ERK1/2 phosphorylation signal that peaked 5 to 15 minutes after stimulation (see Supplemental Figure S1B at http://ajp.amjpathol.org). Similar to thrombin, $0.1 \mu \mathrm{mol} / \mathrm{L}$ P1pal-7 could completely block the PRSFLLRN-induced phospho-ERK (see Supplemental Figure S1B at http://ajp.amjpathol.org). This would sug- gest that unlike i1 pepducins, the i3-loop pepducins are effective inhibitors of PAR1-mediated ERK activation. To determine the specificity of the PAR1 pepducin inhibitors, we tested their effects on the closely related PAR2 and PAR4 receptors. All three PAR1 pepducins were selective for PAR1 and did not cross-inhibit PAR2 or PAR4
A

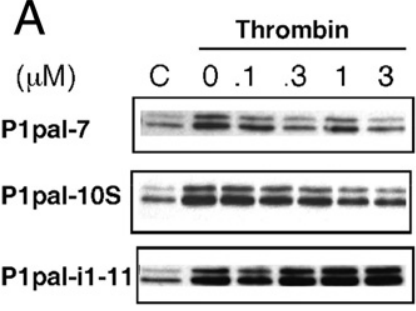

D

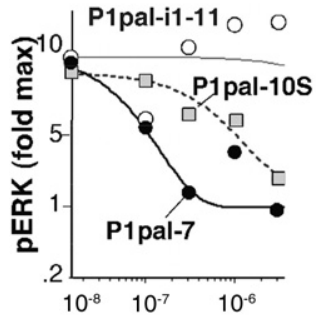

B

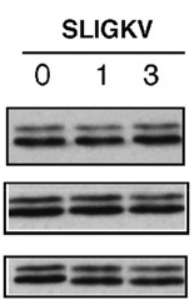

E

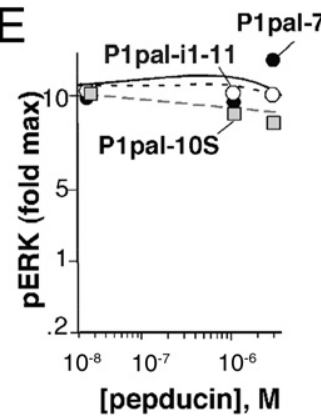

C

\begin{tabular}{ll} 
AYPGKF \\
\hline 0 & 13
\end{tabular}

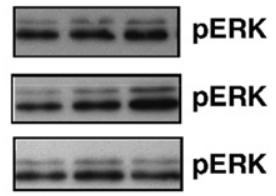

Figure 2. Differential inhibition of PAR1-ERK activation by i3- and i1-derived PAR1 pepducins. A-C: Western blots of lysates from A549 cells untreated, or treated with thrombin, SLIGKV, or AYPGKF. Indicated samples were pretreated with various concentrations $(0.1$ to $3 \mu \mathrm{mol} / \mathrm{L})$ of P1pal-7, P1pal-10S, or P1pal-i1-11 before stimulation and immunoblotted with anti-phosphoERK. D-F: Quantification of the Western blots in A-C were conducted by densitometry and results are expressed relative to maximum (fold max) phosphorylation of pERK 

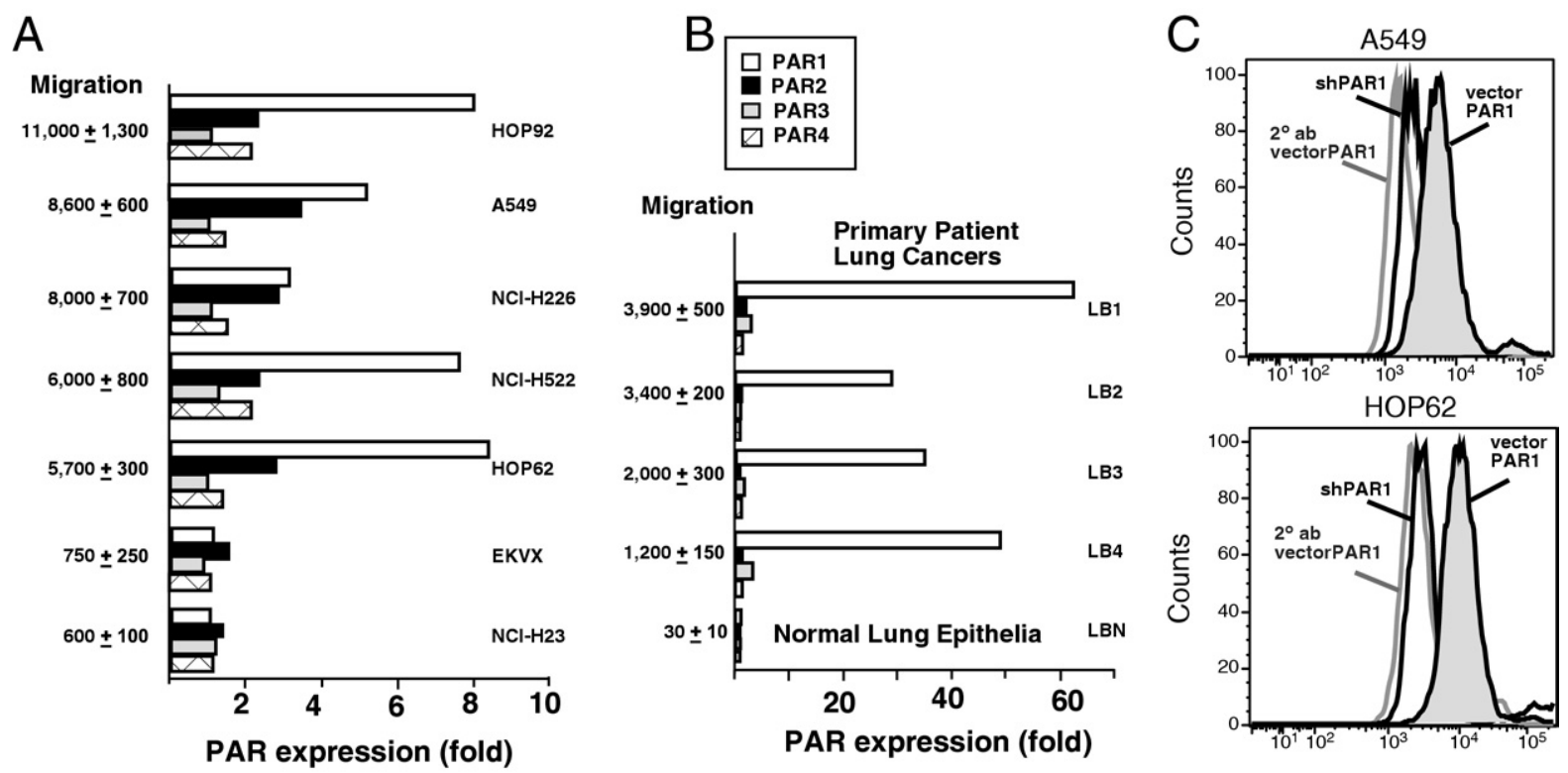

$\mathrm{D}$
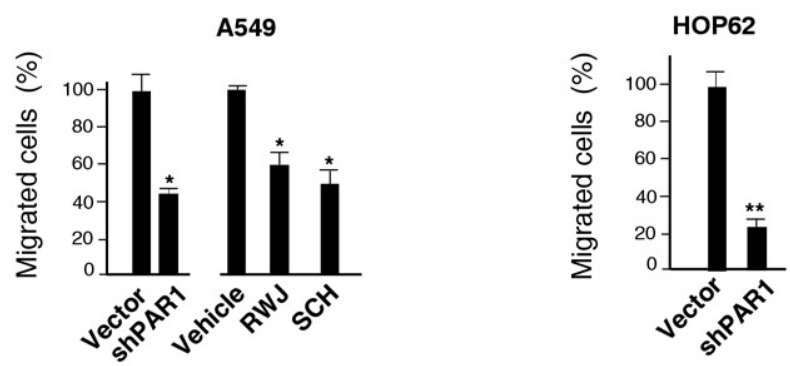

Figure 3. PAR expression profile in lung cancer. Lung cancer cell lines ( $n=7)$ from the NCI-60 panel were characterized for surface expression of PAR1, PAR2, PAR3, and PAR4 (A) as previously described. ${ }^{5}$ B: PAR mRNA expression profile in patient samples. Quantitative real-time PCR analysis of PAR1 to PAR4 (corrected for actin expression as internal control) and expressed as fold increase over nonmalignant lung tissue. Migration of lung carcinoma cell lines toward fibroblast conditioned media is expressed as cell number \pm SD. C: Silencing of PAR1 expression in A549 and HOP62 cells with shPAR1 or vector control. Surface expression of PAR1 was determined by flow cytometry using SFLLR-Ab. D: Migration of A549 and HOP62 lung cancer cells toward NIH-3T3 conditioned media supplemented with RWJ-56110 $(10 \mu \mathrm{mol} / \mathrm{L})$ and SCH7979 $(50 \mu \mathrm{mol} / \mathrm{L})$ or vehicle $(0.2 \%$ dimethyl sulfoxide). Migration of lung cancer cells treated with shPAR1 treatment or appropriate controls toward NIH-3T3 conditioned media. Basal migration toward conditioned media (vehicle treated or vector control) was normalized to $100 \%$. ${ }^{*} P<0.05,{ }^{* *} P<0.01$.

mediated ERK phosphorylation at 1- to 3- $\mu \mathrm{mol} / \mathrm{L}$ concentrations (Figure 2, B, C, E, and F).

\section{PAR1 Expression Is Increased in Highly Aggressive Lung Cancer Cell Lines}

A previous histologic analysis suggested that proteaseactivated receptors PAR1 and PAR4 may have a negative prognostic predictive value on outcome from a study of 60 NSCLC patients, including 30 adenocarcinomas and 30 squamous cell carcinomas. ${ }^{30}$ We determined surface expression of all four PAR members in seven different National Cancer Institute ( $\mathrm{NCl}$ )-lung cancer cell lines that consisted of five adenocarcinomas, a squamous-cell carcinoma, and a large cell carcinoma using flow cytometry. Of the four PAR family members, PAR1 expression was increased threefold to ninefold in the majority of the lung carcinomas, with maximum expression detected in the adenocarcinomas. In contrast, there was only a modest increase of the three other PARs including PAR4 (Figure 3A). High PAR1-expressing cells showed a 7- to 18-fold higher rate of migration towards conditioned media than the two low-expressing PAR1 cell lines (EKVX and $\mathrm{NCl}-\mathrm{H} 23$ ).

To validate the expression of PARs in primary tumor specimens we measured the mRNA levels using quantitative PCR in five lung specimens isolated from patients who underwent thoracotomy. Based on histopathology, the primary tumors included two adenocarcinomas, one poorly differentiated NSCLC, one squamous carcinoma, and one benign lung specimen. As shown in Figure 3B, patient lung carcinomas had high levels of PAR1 mRNA and low levels of PAR2, PAR3, and PAR4 mRNA. As was observed with the $\mathrm{NCl}$ lung carcinomas, high PAR1 expression in the patient tumors also was accompanied with a large 10- to 40-fold increase in migration of all four primary lung tumor cells as compared with the normal lung tissue.

To further validate the role of PAR1 in lung cancer cell motility, we tested the effect of silencing PAR1 gene expression using PAR1 short hairpin RNA in two high PAR1-expressing adenocarcinomas, A549 and HOP62. The PAR1 short hairpin RNA silenced the majority of the PAR1 expression in both cell lines $(80 \% \pm 5 \%$ and 
A

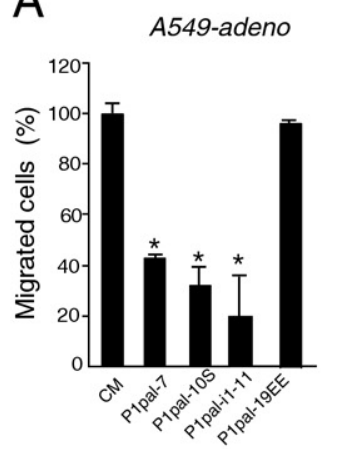

B

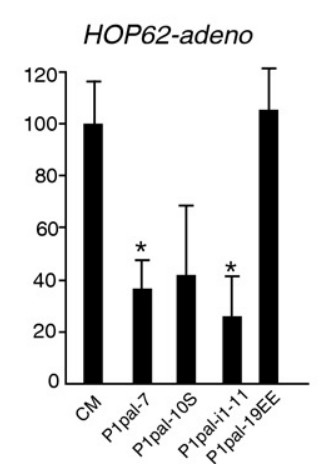

C
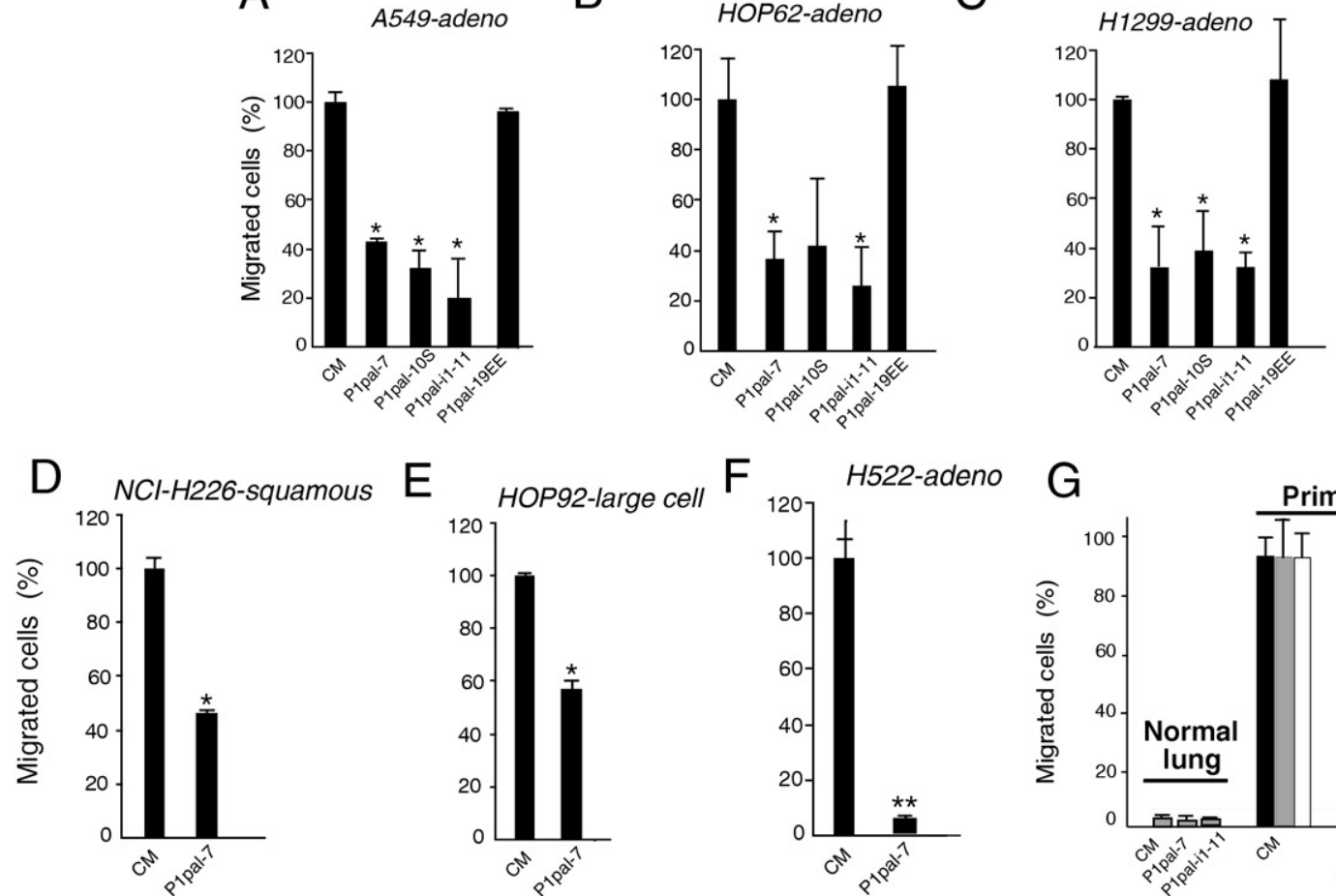

E

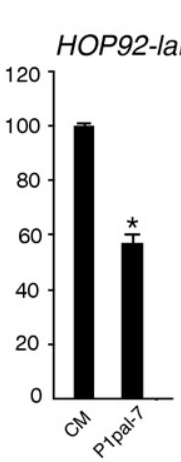

$\mathrm{F}$

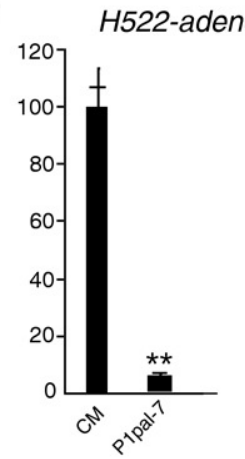

\section{G}

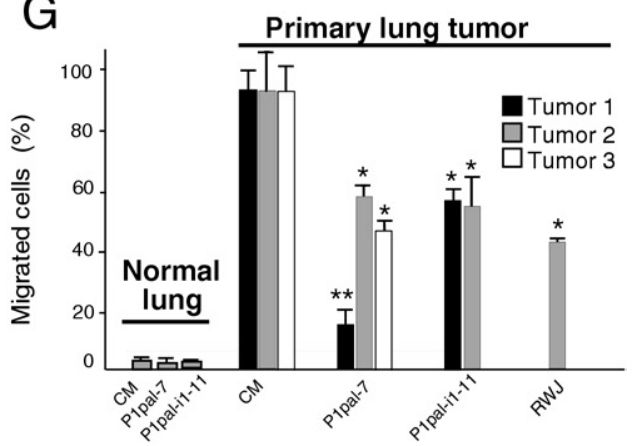

Figure 4. PAR1 is a promigratory factor in lung cancer cells. A-F: Inhibition of lung cancer migration in adenocarcinomas A549, HOP62, H1299 and H522, H226 squamous, and HOP92 large cell using PAR1 pepducins. Pepducins at $3 \mu \mathrm{mol} / \mathrm{L}$ (P1pal-7, P1pal-10S, P1pal-i1-11, or negative control P1pal-19EE) were added to the lower well. G: Cell from primary lung tumors or nonmalignant control were pretreated with PAR1 pepducins and migration was determined $\left({ }^{*} P<0.05\right.$, $\left.{ }^{* * *} P<0.01\right)$.

$90 \% \pm 5 \%$ ) (Figure 3C). Next, we tested the effect of PAR1 loss on cellular migration using a Boyden chamber migration assay and found that PAR1 knockdown suppressed migration by $55 \% \pm 5 \%$ in A549 cells toward $\mathrm{NIH}-3 \mathrm{~T} 3$ conditioned media, and by $80 \% \pm 5 \%$ in HOP62 cells after long-term puromycin selection of shPAR 1 and the vector control-treated cells (Figure 3D).

Because A549 is the cell line that was characterized further in all subsequent in vitro and in vivo experiments we also tested the effect of the PAR1 antagonists based on extracellular ligand RWJ-56110 (10 $\mu \mathrm{mol} / \mathrm{L})$ and SCH7979 (50 $\mu \mathrm{mol} / \mathrm{L}$ ) and found $40 \%$ to $50 \%$ inhibition in migration (Figure 3D). These data are consistent with our previous findings ${ }^{4,5,7}$ that silencing of PAR1 in breast cancer cells is associated with decreased migration.

\section{PAR1 i1 and i3 Pepducins Inhibit Migration of Lung Carcinomas}

Given that silencing of PAR1 expression decreased migration, we tested whether i1 and i3 PAR1 antagonist pepducins would have similar effects on migration of the four $\mathrm{NCl}$ lung cell adenocarcinomas (A549, HOP62, H522, and H1299), one large cell (HOP92), one squamous carcinoma $(\mathrm{H} 226)$, along with three primary patient tumors that consisted of two adenocarcinomas, one poorly differentiated NSCLC, and one normal lung epithelia. Migration of the PAR1-expressing adenocarcinomas were suppressed by $60 \%$ to $80 \%$ by all three pepducins (Figure $4 \mathrm{~A}-\mathrm{C}$ ), which was highly similar to the effects seen earlier by PAR1 short hairpin RNA treatment. The negative control PAR1 i3 pepducin, P1pal-19EE, had no effect on migration. P1pal-7 provided $40 \%$ to $90 \%$ inhibition with $\mathrm{H} 226$ squamous, HOP92 large cell carcinoma, and H522 adenocarcinoma (Figure 4D-F), providing further support that PAR1 signaling plays an important role in lung cancer cell migration. We tested whether the PAR1 antagonist pepducins could confer cytotoxicity to lung carcinoma cells using MTT assay. We found that pretreatment of A549, H1299, or HOP62 with pertussis toxin, which inactivates $\mathrm{Gi}$, results in similar inhibition of migration as PAR1 blockade (see Supplemental Figure S2 at $h$ ttp://ajp.amjpathol.org). As shown in Supplemental Figure S3A (available at http://ajp.amjpathol.org), exposure of A549, HOP62, and HOP92 lung carcinoma cell lines to $3 \mu \mathrm{mol} / \mathrm{L}$ pepducins over the 5 -hour period of cell migration had no significant effects on cell viability. However, over 3-day periods, A549 cells were most sensitive to the i3-derived P1pal-10S and P1pal-7 pepducins and less sensitive to the i1-derived P1pal-i1-11 (see Supplemental Figure S3B at http://ajp.amjpathol.org).

We determined whether migration of the primary carcinoma cell lines isolated from lung tumors could be inhibited by PAR1 pepducins (Figure 4G). PAR1 pepducins significantly inhibited migration (40\% to $80 \%$ ) of primary lung tumors with comparable efficacy using either P1pal-7 (i3)- or the P1pal-i1-11. Likewise, the RWJ56110 small-molecule antagonist of PAR $1^{48}$ suppressed up to $55 \%$ of the migration of primary lung tumor cells toward NIH-3T3 conditioned media. The PAR1 antagonist 
A

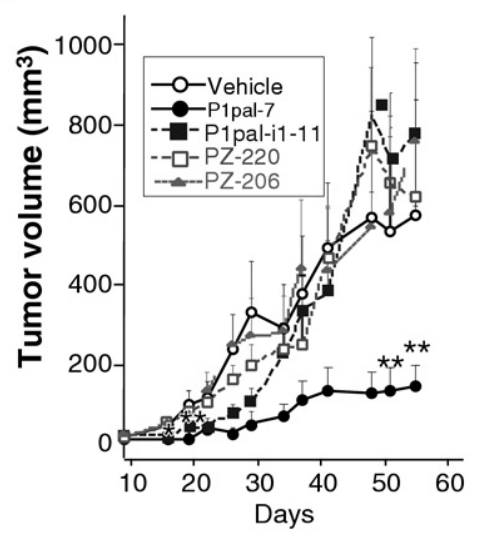

C

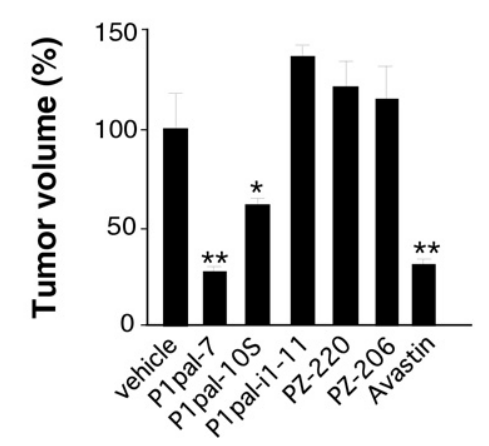

B
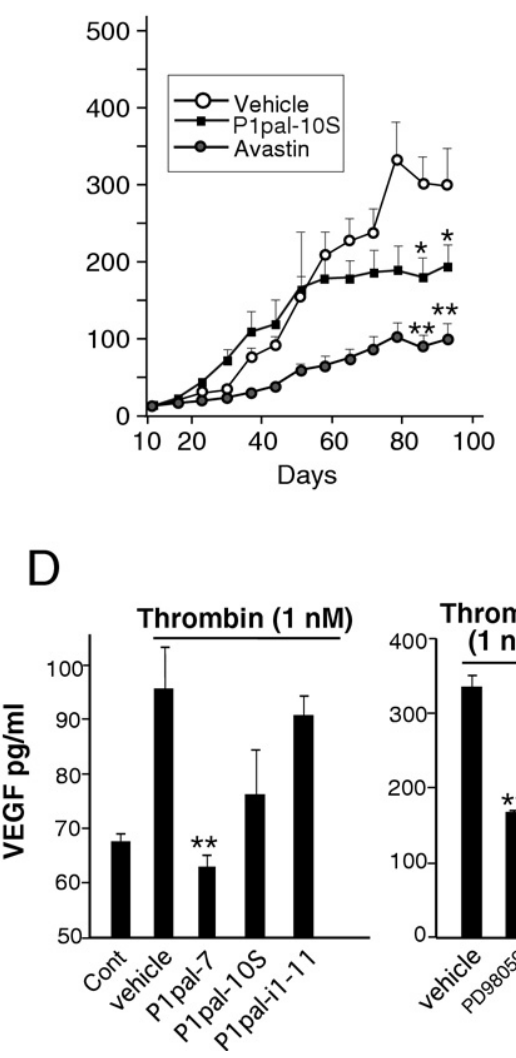

Figure 5. Monotherapy with PAR1-i3 pepducins inhibits tumor progression of A549 xenografts. A and B: A549 mice treated with vehicle, P1pal-7, P1pal-i1-11, P1pal-10S, X1/2-i1, X1/2-i3, or Avastin. Each time point represents the mean \pm SE. C: Final tumor volume at the completion of the experiment was calculated as a percentage of untreated vehicle control. D: Serum-starved A549 adenocarcinoma cells were pretreated with P1pal-7, P1pal-10S, P1pal-i1-11, vehicle, or PD98059 and stimulated with thrombin. VEGF production was assessed by enzyme-linked immunosorbent assay. Data are expressed as mean $\pm \mathrm{SD}\left({ }^{*} P<0.05\right.$ $\left.{ }^{* * *} P<0.01\right)$. pepducin P1pal-7 and P1pal-i1-11 had no effect on the low-expressing PAR1 cell line derived from benign lung tissue, which migrated poorly (Figure 4G). Together, these results suggest that PAR1 is an important contributor migration in lung carcinoma cells and pepducin antagonists are effective in blocking PAR1-mediated migration in both established cell lines and primary patient lung carcinomas.

\section{The PAR1 i3 Pepducin Inhibits Tumor Growth of Lung Carcinomas in Xenograft Models}

PAR1 expression level is correlated with reduced survival of patients with NSCLC. ${ }^{30}$ To define the relative importance of PAR1 in lung tumor progression we used in vivo mouse models. Furthermore, because we identified that blockade of PAR1 signaling with i3 pepducins blocks multiple signaling pathways including calcium signaling and the ERK1/2 pathway, whereas i1 pepducin inhibits only migration and partially inhibits calcium, it was of interest to compare the in vivo efficacy of these pepducins. An A549 lung adenocarcinoma xenograft model in nude mice was used to evaluate monotherapy with P1pal-7, P1pal-10S, P1pal-i1-11, or the VEGF antagonist Avastin. For comparison, we also tested CXCR1/2 pepducins $^{32} \times 1 / 2$ pal-i1 and X1/2pal-i3 that previously were shown to inhibit inflammation ${ }^{32}$ and CXCR1/2-driven angiogenesis in ovarian cancer. ${ }^{38}$ We found that the i3derived P1pal-7 and Avastin gave comparable significant reductions $(P<0.01)$ in tumor progression with $75 \%$ inhibition (Figure $5 \mathrm{~A}-\mathrm{C}$ ). There was also a significant reduction $(P<0.05)$ in tumor growth using the i3-derived P1pal-10S with 40\% inhibition, but the i1-derived P1pali1-11 did not inhibit the long-term growth of the A549 tumors. Interestingly, the i1-derived P1pal-i1-11 was initially effective for the first 3 weeks and achieved significant blockade of tumor growth by day $20(P<0.01)$. However, after this early protective stage there was a rapid escape in tumor growth with the i1-derived pepducin. Tumor growth reduction with i3-derived pepducin treatments was accompanied by necrosis. The CXCR1/ 2-derived X1/2pal-i3 and X1/2pal-i1 pepducins had no effect on tumor growth. These results suggest that monotherapy with i3-derived PAR1 pepducins may provide significant inhibition of lung carcinoma tumor growth in mice and identify PAR1 as a novel therapeutic target in lung cancer.

PAR1 has been shown to regulate VEGF production in several cell types ${ }^{49}$ and VEGF is highly expressed in primary lung tumors. ${ }^{30}$ Because the i3-based P1pal-7 pepducin had similar efficacy as Avastin in suppressing lung tumor growth of A549 xenografts, we measured VEGF-A production in the A549 tumor cells after 18 hours thrombin treatment. There was a significant two-fold mean increase in thrombin-dependent production of VEGF-A that could be completely blocked by the i3based P1pal-7 and partially blocked with P1pal-10S (Figure 5D). In contrast, the i1-based P1pal-i1-11 did not 


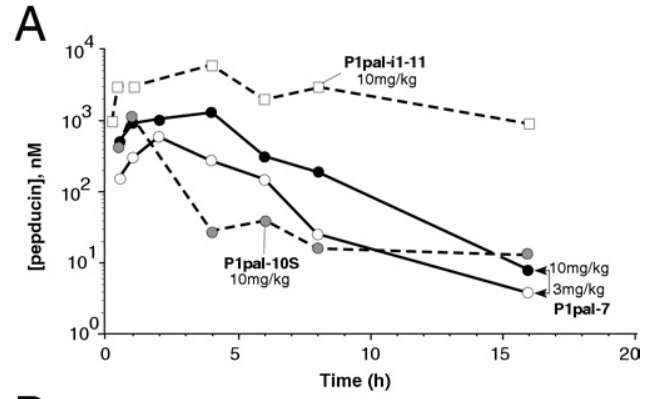

B

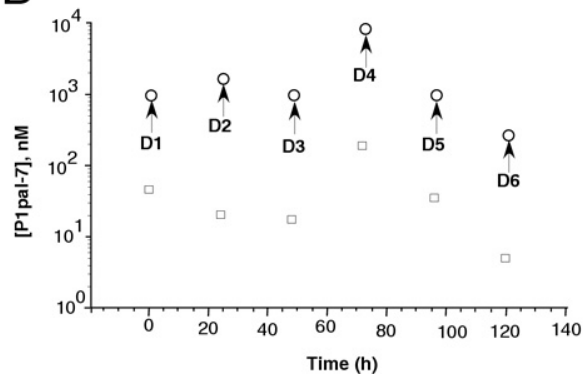

Figure 6. Pharmacokinetics of PAR1 pepducins. A: CF-1 mice were injected subcutaneously with P1pal-7 (3 mg/kg, open circles), P1pal-7 (10 mg/kg, closed circles), P1pal-10S (10 mg/kg, gray circles), or P1pal-i1-11 (10 $\mathrm{mg} / \mathrm{kg}$, open squares) in $20 \%$ dimethyl sulfoxide and blood was collected at indicated time points $(n=3)$. Pepducin levels in plasma were quantified with LC/MS/MS. B: Daily (D1 to D6) plasma levels of P1pal-7 after subcutaneous injection of $10 \mathrm{mg} / \mathrm{kg} \mathrm{P} 1$ pal-7 were measured at 1 hour (open circles) and 24 hours (open squares)

inhibit thrombin-dependent VEGF-A production. Notably, the ERK inhibitor PD98059 also could suppress thrombinmediated VEGF production. Unlike in ovarian cancer, ${ }^{38}$ we found no increase in PAR1-mediated IL-8 production in A549 cells (see Supplemental Figure S4 at http://ajp.amjpathol.org), consistent with the observed lack of efficacy of CXCR1/2 pepducins in the A549 xenograft models. These xenograft data provide support for the role of a novel PAR1-ERK1/2-VEGF paracrine pathway that is an effective therapeutic target in the A549 adenocarcinoma lung cancer model.

\section{Pharmacokinetics of PAR1 Pepducins}

Pharmacokinetics of plasma levels of P1pal-7, P1pal10S, and P1pal-i1-11 at 30 minutes, and at 1, 2, 4, 6, 8, and 16 hours was measured by LC/MS/MS to determine steady-state pepducin drug levels and the rate of elimination from mice. Subcutaneous injections of P1pal-7 (3 $\mathrm{mg} / \mathrm{kg}$ or $10 \mathrm{mg} / \mathrm{kg}$ ) into wild-type CF-1 mice (25 to $30 \mathrm{~g}$ ) was followed by blood collection at various time points from the vena cava. As shown in Figure 6A, the peak plasma level of P1pal-7 (10 mg/kg) reached $1.1 \mu \mathrm{mol} / \mathrm{L}$, which persisted for 4 hours followed by elimination to 0.2 $\mu \mathrm{mol} / \mathrm{L}$ at the 6-hour time point. Residual P1pal-7 levels were $10 \mathrm{nmol} / \mathrm{L}$ at the 16-hour time point. After the 4-hour plateau, the elimination rate was linear from 4 to 16 hours. The peak plasma level of $3 \mathrm{mg} / \mathrm{kg}$ P1pal-7 reached 0.6 $\mu \mathrm{mol} / \mathrm{L}$ at 2 hours and elimination was linear between 2 hours and 16 hours. P1pal-10S (10 mg/kg) gave similar peak plasma level of $1.0 \mu \mathrm{mol} / \mathrm{L}$ as P1pal-7 $(10 \mathrm{mg} / \mathrm{kg})$ at
1 hour. However, there was rapid clearance after 1 hour. In contrast to P1pal-10S, P1pal-i1-11 (10 mg/kg) had a sustained plasma half-life with a peak plasma level of 5.0 $\mu \mathrm{mol} / \mathrm{L}$ between 0.5 and 8 hours.

Lastly, we measured the peak plasma level of P1pal-7 (10 mg/kg) before and 1 hour after once-daily subcutaneous injection over 6 days to determine whether the peak plasma levels were consistent on daily administration. As shown in Figure 6B, there was a relatively consistent peak plasma concentration of approximately 1 to $2 \mu \mathrm{mol} / \mathrm{L}$ P1pal-7, 1 hour after daily administration over 6 days. These results also indicate that after daily subcutaneous dosing, P1pal-7 does not accumulate in plasma in the mouse.

\section{Discussion}

Emerging histopathologic evidence suggests that high expression of the G-protein-coupled PAR1 receptor is accompanied by an aggressive phenotype and poor outcome in patients with NSCLC. ${ }^{30}$ In agreement with these clinicopathologic findings, we documented an increase in functional PAR1 protein, mRNA expression, and PAR1dependent motility in a panel of $\mathrm{NCl}$ carcinomas and primary lung specimens as compared with normal lung epithelia. Silencing of PAR1 or pharmacologic blockade of PAR1 caused a significant decrease in motility of lung cancer cells. In contrast, the $\mathrm{NCl}$ lung adenocarcinomas and primary lung adenocarcinomas did not have increased levels of the related PAR2, PAR3, or PAR4 receptors.

By using pepducin technology directed against the intracellular loops of PAR1 we delineated divergent signaling pathways dependent on the i1 versus i3 loops in lung adenocarcinoma cell lines. Pepducins are lipidated peptides that are specifically targeted to the intracellular surface of their cognate GPCR, resulting in modulation of signal transduction. ${ }^{21,22,31,32,50,51}$ Pepducins targeting the PAR1 i3 loop completely inhibited cell motility, calcium mobilization, and ERK $1 / 2$ activation. In contrast, the i1-targeted PAR1 pepducin inhibited cell motility, but did not have any effect on ERK $1 / 2$ activation and only partially suppressed calcium mobilization. These in vitro inhibitory data were highly concordant with the divergent pharmacologic effects of the i3 versus i1 pepducins observed in lung tumor models. The i3- and i1-targeted PAR1 pepducins were compared for efficacy in xenografts of A549 lung adenocarcinoma in nude mice. The i3-loop pepducins were efficacious as monotherapy in significantly blocking lung tumor growth whereas the i1 pepducin was ineffective. From these in vitro and in vivo data, we conclude that blockade of i3-loop functions including ERK1/2 activation and potentially calcium signaling may be more important than solely impacting cell motility as occurs with the i1-directed pepducin in our lung adenocarcinoma models. In this regard, it previously was shown ${ }^{4,52}$ that PAR1 signals to ERK1/2 through both $\mathrm{Gi}$ and $\mathrm{Gq}$ proteins in rat astrocytes and that the $\mathrm{Gq}$ ERK $1 / 2$ pathway is modulated by calcium. Because the i3-targeted pepducins were highly effective in blocking 
both PAR1-dependent calcium mobilization and ERK1/2 phosphorylation as compared with the i1-targeted pepducins, it is possible that the PAR1 i3 loop is more important for Gq functions than the i1 loop. Conversely, both the i1- and i3-targeted pepducins were equally effective in suppressing cell motility, which is largely dependent on Gi signaling, providing evidence that both i1 and i3 are important for coupling to Gi. These findings further reinforce the notion that understanding the distinct roles of the downstream PAR1 signaling pathways and their contribution to lung tumor pathogenesis will lead to improved predictive screening assays in the new field of cancer GPCR drug development.

The histopathology studies by Ghio et $\mathrm{al}^{30}$ in 60 NSCLC patient samples also found that the majority (70\%) of human lung tumors express the angiogenic factor VEGF and revealed a significant positive correlation between PAR-1 and VEGF expression $(P<0.01)$. Interestingly, we found that the VEGF antibody, Avastin, had comparable efficacy as the PAR1 i3-loop pepducins in inhibiting human lung tumor growth in nude mice. Because Avastin specifically blocks human VEGF but is ineffective against mouse-derived VEGF, the observed effects of Avastin were likely owing to inhibition of the human lung adenocarcinoma-derived VEGF in the mouse xenografts. Indeed, we showed that PAR1 stimulates VEGF production through an ERK1/2-dependent pathway in the lung carcinoma cells. Moreover, PAR1-dependent production of VEGF was effectively blocked by the i3-loop pepducin but not by the i1-targeted pepducin, identifying PAR1-ERK $1 / 2$ signaling as a potentially important regulator of VEGF production in human lung carcinomas. These data also are consistent with the observed anti-angiogenic effects of the PAR1 i3 pepducin, P1pal-7, in xenograft models of invasive breast and ovarian tumors in mice. ${ }^{4,6}$

Lastly, it was of interest to determine the pharmacokinetics of the i1 and i3 pepducins in mouse plasma to gain a better understanding of their in vivo properties. Of the two i3-derived pepducins, P1pal-7 had higher sustained levels than P1pal-10S in plasma and was also more efficacious in the lung tumor models. P1pal-10S (palNRSKKSSALF) has a 3 amino acid N-terminal extension from the lipid tag as compared with the P1pal-7 (palKKSRALF), which may lead to enhanced accessibility to serine-protease cleavage, ${ }^{53}$ although this remains to be determined. By comparison, the i1-targeted pepducin, P1pal-i1-11 (pal-ILKMKVKKPAV), had remarkably high and sustained plasma levels up to 15 hours after single injection in mice, indicating that the pharmacokinetic properties of pepducins for the same receptor are highly sequence dependent and that the pharmacokinetic properties of a particular pepducin may be altered by point mutations or other modifications. ${ }^{50}$ Nonetheless, despite having very high and sustained plasma levels, the i1targeted pepducin, P1pal-i1-11, had limited efficacy in the mouse xenograft models. The poor efficacy of P1pali1-11 was correlated with its inability to block PAR1-dependent ERK $1 / 2$ signaling and VEGF production, which may override the importance of having sustained drug levels. The insight gained from these data indicate that i3-targeted pepducins afford higher efficacy than i1targeted pepducins in lung adenocarcinomas and suggest that PAR1 may be an new therapeutic target in lung cancer.

\section{References}

1. Jemal A, Siegel R, Ward E, Murray T, Xu J, Thun MJ: Cancer statistics, 2007. CA Cancer J Clin 2007, 57:43-66

2. Dempke WC, Suto T, Reck M: Targeted therapies for non-small cell lung cancer. Lung Cancer 2010, 67:257-274

3. Herbst RS, Lynch TJ, Sandler AB: Beyond doublet chemotherapy for advanced non-small-cell lung cancer: combination of targeted agents with first-line chemotherapy. Clin Lung Cancer 2009, 10: $20-27$

4. Boire A, Covic L, Agarwal A, Jacques S, Sherifi S, Kuliopulos A: PAR1 is a matrix metalloprotease-1 receptor that promotes invasion and tumorigenesis of breast cancer cells. Cell 2005, 120:303-313

5. Nguyen N, Kuliopulos A, Graham RA, Covic L: Tumor-derived Cyr61 (CCN1) promotes stromal matrix metalloproteinase-1 production and protease-activated receptor 1-dependent migration of breast cancer cells. Cancer Res 2006, 66:2658-2665

6. Agarwal A, Covic L, Sevigny LM, Kaneider NC, Lazarides K, Azabdaftari G, Sharifi S, Kuliopulos A: Targeting a metalloprotease-PAR1 signaling system with cell-penetrating pepducins inhibits angiogenesis, ascites, and progression of ovarian cancer. Mol Cancer Ther 2008, 7:2746-2757

7. Yang E, Boire A, Agarwal A, Nguyen N, O'Callaghan K, Tu P, Kuliopulos A, Covic L: Blockade of PAR1 signaling with cell-penetrating pepducins inhibits Akt survival pathways in breast cancer cells and suppresses tumor survival and metastasis. Cancer Res 2009, 69: 6223-6231

8. Vu T-KH, Hung DT, Wheaton VI, Coughlin SR: Molecular cloning of a functional thrombin receptor reveals a novel proteolytic mechanism of receptor action. Cell 1991, 64:1057-1068

9. Nystedt S, Emilsson K, Wahlestedt C, Sundelin J: Molecular cloning of a potential proteinase activated receptor. Proc Natl Acad Sci U S A 1994, 91:9208-9212

10. Ishihara $\mathrm{H}$, Connolly AJ, Zeng D, Kahn ML, Zheng YW, Timmons C, Tram T, Coughlin SR: Protease-activated receptor 3 is a second thrombin receptor in humans. Nature 1997, 386:502-506

11. Xu W-F, Andersen H, Whitmore TE, Presnell SR, Yee DP, Ching A, Gilbert T, Davie EW, Foster DC: Cloning and characterization of human protease-activated receptor 4. Proc Natl Acad Sci U S A 1998 , 95:6642-6646

12. Schmidt VA, Nierman WC, Maglott DR, Cupit LD, Moskowitz KA Wainer JA, Bahou WF: The human proteinase-activated receptor-3 (PAR-3) gene. Identification within a Par gene cluster and characterization in vascular endothelial cells and platelets. J Biol Chem 1998, 273:15061-15068

13. Kahn ML, Zheng Y-W, Huang W, Bigornia V, Zheng D, Moff S, Farese RV, Tam C, Coughlin SR: A dual thrombin receptor system for platelet activation. Nature 1998, 394:690-694

14. Bohm SK, Kong W, Bromme D, Smeekens SP, Anderson DC, Connolly A, Kahn M, Nelken NA, Coughlin SR, Payan DG, Bunnett NW: Molecular cloning, expression and potential functions of the human proteinase-activated receptor-2. Biochem J 1996, 314:1009-1016

15. Trivedi V, Boire A, Tchernychev B, Kaneider NC, Leger AJ, O'Callaghan K, Covic L, Kuliopulos A: Platelet matrix metalloprotease- 1 mediates thrombogenesis by activating PAR1 at a cryptic ligand site. Cell 2009, 137:332-343

16. Vassallo RR, Kieber-Emmons T, Cichowski K, Brass LR: Structurefunction relationships in the activation of platelet thrombin receptors by receptor-derived peptides. J Biol Chem 1992, 267:6081-6085

17. al-Ani B, Saifeddine M, Hollenberg MD: Detection of functional receptors for the proteinase-activated-receptor-2-activating polypeptide. SLIGRL-NH2, in rat vascular and gastric smooth muscle. Can J Physiol Pharmacol 1995, 73:1203-1207

18. Ossovskaya VS, Bunnett NW: Protease-activated receptors: contribution to physiology and disease. Physiol Rev 2004, 84:579-621 
19. Griffin CT, Srinivasan Y, Zheng Y-W, Huang W, Coughlin SR: A role for thrombin receptor signaling in endothelial cells during embryonic development. Science 2001, 293:1666-1670

20. Borensztajn K, von der Thusen JH, Peppelenbosch MP, Spek CA The coagulation factor $\mathrm{Xa} /$ protease activated receptor-2 axis in the progression of liver fibrosis: a multifaceted paradigm. J Cell Mol Med 2010, 14:143-153

21. Leger AJ, Jacques SL, Badar J, Kaneider NC, Derian CK, AndradeGordon P, Covic L, Kuliopulos A: Blocking the protease-activated receptor 1-4 heterodimer in platelet-mediated thrombosis. Circulation 2006, 113:1244-1254

22. Kaneider NC, Leger AJ, Agarwal A, Nguyen N, Perides G, Derian C, Covic L, Kuliopulos A: 'Role reversal' for the receptor PAR1 in sepsisinduced vascular damage. Nat Immunol 2007, 8:1303-1312

23. Nierodzik ML, Chen K, Takeshita K, Li JJ, Huang YQ, Feng XS D'Andrea MR, Andrade-Gordon P, Karpatkin S: Protease-activated receptor 1 (PAR-1) is required and rate-limiting for thrombin-enhanced experimental pulmonary metastasis. Blood 1998, 92:36943700

24. Tellez C, Bar-Eli M: Role and regulation of the thrombin receptor (PAR-1) in human melanoma. Oncogene 2003, 22:3130-3137

25. Even-Ram S, Uziely B, Cohen P, Grisaru-Granovsky S, Maoz M Ginzburg Y, Reich R, Vlodavsky I, Bar-Shavit R: Thrombin receptor overexpression in malignant and physiological invasion processes. Nat Med 1998, 4:909-914

26. Henrikson KP, Salazar SL, Fenton JW, Pentecost BT: Role of thrombin receptor in breast cancer invasiveness. Br J Cancer 1999, 79:401-406

27. Rudroff C, Seibold S, Kaufmann R, Zetina CC, Reise K, Schafer U, Schneider A, Brockmann M, Scheele J, Neugebauer EA: Expression of the thrombin receptor PAR-1 correlates with tumour cell differentiation of pancreatic adenocarcinoma in vitro. Clin Exp Metastasis 2002, 19:181-189

28. Whitehead I, Kirk H, Kay R: Expression cloning of oncogenes by retroviral transfer of cDNA libraries. Mol Cell Biol 1995, 15:704-710

29. Martin CB, Mahon GM, Klinger MB, Kay RJ, Symons M, Der CJ Whitehead IP: The thrombin receptor, PAR-1, causes transformation by activation of Rho-mediated signaling pathways. Oncogene 2001 20:1953-1963

30. Ghio P, Cappia S, Selvaggi G, Novello S, Lausi P, Zecchina G, Papotti M, Borasio P. Scagliotti GV: Prognostic role of protease-activated receptors 1 and 4 in resected stage IB non-small-cell lung cancer Clin Lung Cancer 2006, 7:395-400

31. Covic L, Gresser AL, Talavera J, Swift S, Kuliopulos A: Activation and inhibition of $\mathrm{G}$ protein-coupled receptors by cell-penetrating membrane-tethered peptides. Proc Natl Acad Sci U S A 2002, 99:643-648

32. Kaneider NC, Agarwal A, Leger AJ, Kuliopulos A: Reversing systemic inflammatory response syndrome with chemokine receptor pepducins. Nat Med 2005, 11:661-665

33. Hollenberg MD, Saifeddine M, Sandhu S, Houle S, Vergnolle N Proteinase-activated receptor-4: evaluation of tethered ligand-derived peptides as probes for receptor function and as inflammatory agonists in vivo. Br J Pharmacol 2004, 143:443-454

34. Slofstra SH, Bijlsma MF, Groot AP, Reitsma PH, Lindhout T, ten Cate $\mathrm{H}$, Spek CA: Protease-activated receptor-4 inhibition protects from multiorgan failure in a murine model of systemic inflammation. Blood 2007, 110:3176-3182

35. Covic L, Misra M, Badar J, Singh C, Kuliopulos A: Pepducin-based intervention of thrombin receptor signaling and systemic platelet activation. Nat Med 2002, 8:1161-1165

36. Kamath L, Meydani A, Foss F, Kuliopulos A: Signaling from proteaseactivated receptor -1 inhibits migration and invasion of breast cancer cells. Cancer Res 2001, 61:5933-5940

37. Hatziapostolou M, Polytarchou C, Panutsopulos D, Covic L, Tsichlis PN: Proteinase-activated receptor-1-triggered activation of tumor progression locus-2 promotes actin cytoskeleton reorganization and cell migration. Cancer Res 2008, 68:1851-1861

38. Agarwal A, Tressel SL, Kaimal R, Balla M, Lam FH, Covic L, KuliopuIos A: Identification of a metalloprotease-chemokine signaling system in the ovarian cancer microenvironment: implications for antiangiogenic therapy. Cancer Res 2010, 70:5880-5890

39. Palczewski K, Kumasaka T, Hori T, Behnke CA, Motoshima H, Fox BA, Trong IL, Teller DC, Okada T, Stenkamp RE, Yamamoto M Miyano M: Crystal structure of rhodopsin: a G protein-coupled receptor. Science 2000, 289:739-745

40. Swift S, Leger AJ, Talavera J, Zhang L, Bohm A, Kuliopulos A: Role of the PAR1 receptor 8th helix in signaling: the 7-8-1 receptor activation mechanism. J Biol Chem 2006, 281:4109-4116

41. Gabbeta J, Yang X, Kowalska MA, Sun L, Dhanasekaran N, Rao AK Platelet signal transduction defect with $\mathrm{Ga}$ subunit dysfunction and diminished $\mathrm{Ga}_{\mathrm{q}}$ in a patient with abnormal platelet responses. Proc Natl Acad Sci U S A 1997, 94:8750-8755

42. Covic L, Gresser AL, Kuliopulos A: Biphasic kinetics of activation and signaling for PAR1 and PAR4 thrombin receptors in platelets. Biochemistry 2000, 39:5458-5467

43. Roberts PJ, Der CJ: Targeting the Raf-MEK-ERK mitogen-activated protein kinase cascade for the treatment of cancer. Oncogene 2007 26:3291-3310

44. Wang H, Moreau F, Hirota CL, Macnaughton WK: Proteinase-activated receptors induce interleukin-8 expression by intestinal epithelial cells through ERK/RSK90 activation and histone acetylation. FASEB J 2010, 24:1971-1980

45. Shih $\mathrm{CH}$, Bien MY, Chiang LL, Su CL, Lin CH, Chen BC: Thrombin induces cyclooxygenase-2 expression via the ERK and NF-kappaB pathways in human lung fibroblasts. Eur J Pharmacol 2009, 618: $70-75$

46. Wadgaonkar R, Somnay K, Garcia JG: Thrombin induced secretion of macrophage migration inhibitory factor (MIF) and its effect on nuclear signaling in endothelium. J Cell Biochem 2008, 105:1279-1288

47. Wang $H$, Ubl JJ, Stricker R, Reiser G: Thrombin (PAR-1)-induced proliferation in astrocytes via MAPK involves multiple signaling pathways. Am J Physiol Cell Physiol 2002, 283:C1351-C1364

48. Andrade-Gordon $\mathrm{P}$, Maryanoff BE, Derian $\mathrm{CK}$, Zhang $\mathrm{H}-\mathrm{C}$, Addo MF, Darrow AL, Eckardt AJ, Hoekstra WJ, McComsey DF, Oksenberg D, Reynolds EE, Santulli RJ, Scarborough RM, Smith CE, White KB: Design, synthesis, and biological characterization of a peptide-mimetic antagonist for a tethered-ligand receptor. Proc Natl Acad Sci U S A 1999, 96:12257-12262

49. Huang YQ, Li JJ, Hu L, Lee M, Karpatkin S: Thrombin induces increased expression and secretion of VEGF from human FS4 fibroblasts. DU145 prostate cells and CHRF megakaryocytes. Thromb Haemost 2001, 86:1094-1098

50. Covic L, Tchernychev B, Jacques S, Kuliopulos A: Pharmacology and in vivo efficacy of pepducins in hemostasis and arterial thrombosis. Handbook of Cell-Penetrating Peptides 2006, 14:245-257

51. Wielders SJ, Bennaghmouch A, Reutelingsperger CP, Bevers EM, Lindhout T: Anticoagulant and antithrombotic properties of intracellular protease-activated receptor antagonists. J Thromb Haemost 2007, 5:571-576

52. Hollenberg MD: PARs in the stars: proteinase-activated receptors and astrocyte function. Focus on "Thrombin (PAR-1)-induced proliferation in astrocytes via MAPK involves multiple signaling pathways." Am J Physiol Cell Physiol 2002, 283:C1347-C1350

53. Kuliopulos A, Covic L, Seeley SK, Sheridan PJ, Helin J, Costello CE: Plasmin desensitization of the PAR1 thrombin receptor: kinetics. Sites of truncation, and implications for thrombolytic therapy. Biochemistry $1999,38: 4572-4585$ 